\title{
Solid oxide fuel cell and application of proton conducting ceramics
}

\author{
Donghwi Jeong, Guntae Kim \\ UNIST \\ 고체산화물 연료전지와 양성자 전도성 세라믹 물질의 응용
}

\author{
정동휘, 김건태 ${ }^{\dagger}$ \\ 울산과학기술원
}

(Received November 25, 2018; Accepted December 17, 2018)

\begin{abstract}
s
Solid oxide fuel cells (SOFCs) are promising eco-friendly energy conversion system due to their high efficiency, low pollutant emission and fuel flexibility. High operating temperatures, however, leads to the crucial drawbacks such as incompatibility between the components and high thermal stress. Proton-conducting ceramic fuel cells (PCFCs) with proton-conducting oxide (PCO) materials are new types of fuel cells that can solve the problems of conventional SOFCs. Many studies have been proceeded to improve the performance of electrolytes and electrodes, and triple conductive oxides (TCOs) have attracted significant attention as high performance PCFC electrodes.
\end{abstract}

Keywords : Protonic ceramic fuel cell, Fuel cell

\section{1. 서론}

최근 화석연료의 고갈 및 오랜 시간 처리가 필요한 폐 기물 문제가 수면위로 대두됨에 따라 친환경적인 에너지 변환장치의 개발이 주목을 받고 있다. ${ }^{1)}$ 그 중에서도 연료 전지는 기존의 화석연료기반의 발전방식에 비해서 높은 효율을 가짐과 동시에 물이 생성되는 전기화학 반응을 기 반으로 하므로 현재 상용화된 여러 에너지 변환장치들을
대체할 수 있는 친환경적인 에너지 변환장치로써 부족함 이 없다고 할 수 있다. 연료로 주로 사용되는 수소는 기존 의 휘발유와 비교하여 2.75 배 많은 에너지를 생성하며 (수소 $1 \mathrm{~g}$ 당 $122 \mathrm{~kJ}$ ) 온실가스를 배출하지 않는 청정 에 너지원이다. ${ }^{2)}$ 연료전지는 전력 생산시설의 설치 면적이 작고 풍력이나 태양열과 같은 기타 친환경 에너지 발전시 설에 비해서 기후나 날씨, 설치 지역의 환경에 의한 영향 등 외부 요인에 의한 영향이 적다. 풍력의 경우 $5 \sim 10$ 


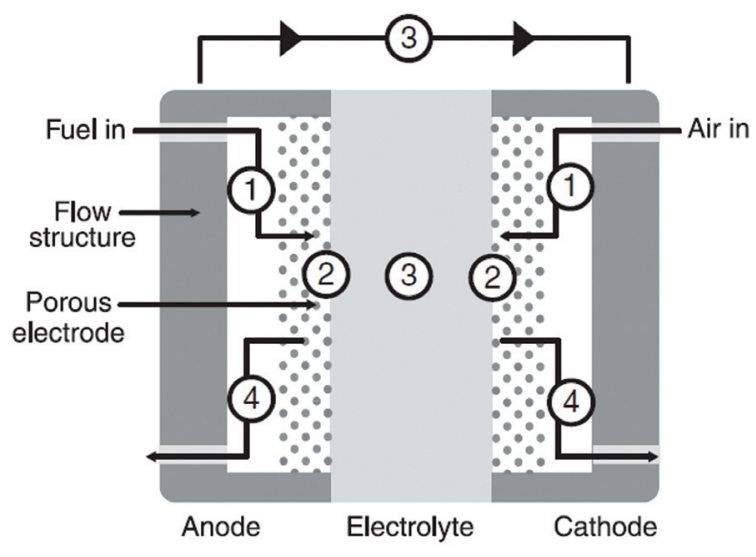

Fig. 1. Cross section of fuel cell illustrating steps in electrochemical reactions ${ }^{3)}$

$\%$, 태양열의 경우 $15 \sim 20 \%$ 의 에너지 변환효율을 보 여주는 것과 비교하여 연료전지는 일반적으로 $70 \%$ 이상 의 에너지 변환효율을 보여준다. 또한 분산발전이 가능하 기 때문에 전기에너지를 사용해야 하는 곳 인근에 설치될 경우 송전에 필요한 최소한의 인프라만을 이용하여 생산 된 전기에너지를 사용하는 것이 가능하다. ${ }^{1,3-5)}$ 이러한 특 성을 이용하여 송전시설 설치가 힘든 도서산간지방에도 환경의 제약 없이 전기에너지의 활용이 가능하다는 장점 이 있다.

위 그림은 연료전지에서 일어나는 전기화학적 반응들 의 주요 단계를 나타낸 단면도이다. 그림에 적힌 숫자에 따라 다음과 같은 반응들이 일어나게 된다.

1. 반응물(연료와 공기)이 각각의 전극에 공급됨

2. 전기화학적 반응이 발생함

3. 전해질을 따라 이온전도가, 외부전선을 따라 전자전 도가 일어나게 됨

4. 반응의 생성물들이 제거됨

위 그림에 묘사된 것처럼 공기극(Cathode, 양극)에는 공기가, 연료극(Anode, 음극)에는 연료가 각각 공급된 다. 공기극에서는 공급된 공기 속 산소가 환원되는 반면 연료극에서는 연료의 산화가 일어나게 된다. 연료전지에 의한 발전은 이와 같은 전기화학 반응이 얼마나 빠르게
일어나는지에 의해 영향을 받으며 이러한 반응이 빠를수 록 높은 출력을 기대할 수 있다. 따라서 연료전지의 성능 은 고효율의 촉매를 개발하여 사용하는 것과 반응이 일어 나는 활성화 영역을 디자인 하는 것에 의해 많은 영향을 받게 된다. 전기화학반응에 의해 생성된 전자와 이온은 다른 전극에서 소모되며 전해질을 따라 일어나는 이온의 전도는 전자전도에 비해 느리다. 그러므로 이온전도는 연료전지의 성능을 판단하는데 중요한 요소 중 하나 다. ${ }^{1,3)}$

연료전지는 사용되는 전해질 물질에 따라 고분자 이온 교환막을 전해질로 사용하는 고분자전해질 연료전지 (PEMFC), 액체 인산을 사용하는 인산형 연료전지 $(\mathrm{PAFC})$, 알칼라인 전해질을 사용하는 알칼리형 연료전 지(AFC), 용융탄산염을 사용하는 용융탄산염 연료전지 $(\mathrm{MCFC})$, 그리고 고체산화물을 사용하는 고체산화물 연 료전지 $(\mathrm{SOFC})$ 등으로 나뉜다. 각 연료전지들은 사용된 전해질에 따라 다른 이온이 전하운반자의 역할을 하며 이 에 따라 각 연료전지의 효율적인 작동에 필요한 작동 환 경, 온도, 필요한 촉매 등이 달라진다. 그 중에서도 산소 이온을 전도하는 세라믹물질을 전해질로 사용하는 고체 산화물 연료전지(SOFC)는 여러 종류의 연료전지들 중에 서도 가장 높은 효율을 가질 뿐만 아니라 높은 작동온도 로 인한 폐열을 재활용 할 수 있다는 점 등 여러 독보적인 장점을 가지고 있다. ${ }^{6-12)}$ 한편 상대적으로 낮은 온도에서 작동하는 $\mathrm{PEMFC}, \mathrm{PAFC}, \mathrm{AFC}$ 의 경우 백금촉매가 필요 하고 별도의 개질기가 없다면 고순도의 수소만 연료로써 사용 가능하다는 단점이 있다. 하지만 $\mathrm{SOFC}$ 의 경우 상 대적으로 저렴한 세라믹 물질을 촉매로써 사용 할 수 있 을 뿐만 아니라 별도의 개질기 없이 기존에 널리 사용되 던 천연가스, $\mathrm{LPG}$, 부탄가스 등의 화석연료뿐만 아니라 바이오연료까지 연료로써 사용이 가능하다. ${ }^{3,6)}$ 연료선택 에 대한 유연성이 뛰어난 $\mathrm{SOFC}$ 의 장점은 미래에 구축될 수소기반 에너지사회는 물론 현재 화석연료 기반의 시스 템에서도 가장 유리한 고지에 올라있다고 할 수 있다. 따 라서 이와 같은 $\mathrm{SOFC}$ 의 특징들은 앞으로 연료전지기반 의 에너지 공급 시스템의 상용화를 앞당길 수 있을 것으 로 보인다. 
$\mathrm{CE}$

특 집 ㅁㅁ 정동휘, 김건태

Table 1. Description of major fuel cell types ${ }^{3,13)}$

\begin{tabular}{c|c|c|c|c|c}
\hline & $\mathrm{PEMFC}$ & $\mathrm{PAFC}$ & $\mathrm{AFC}$ & $\mathrm{MCFC}$ & $\mathrm{SOFC}$ \\
\hline Electrolyte & 고분자 분리막 & 액체 $\mathrm{H} 3 \mathrm{PO} 4$ & 액체 $\mathrm{KOH}$ & 용융탄소염 & 고체산화물 \\
\hline Charge carrier & $\mathrm{H}+$ & $\mathrm{H}+$ & $\mathrm{OH}-$ & $\mathrm{CO}_{3}{ }^{2-}$ & $\mathrm{O}^{2-}$ \\
\hline Operating temperature & $80{ }^{\circ} \mathrm{C}$ & $200{ }^{\circ} \mathrm{C}$ & $60 \sim 200{ }^{\circ} \mathrm{C}$ & $650{ }^{\circ} \mathrm{C}$ & $600 \sim 1000{ }^{\circ} \mathrm{C}$ \\
\hline Catalyst & $\mathrm{Pt}$ & $\mathrm{Pt}$ & $\mathrm{Pt}$ & $\mathrm{Ni}$ & Perovskites \\
\hline Cell component & Carbon based & Carbon based & Carbon based & Stainless based & Ceramic based \\
\hline Fuel compatibility & $\mathrm{H}_{2}$ & $\mathrm{H}_{2}$ & $\mathrm{H}_{2}$ & $\mathrm{H}_{2,} \mathrm{CH}_{4}$ & $\mathrm{H}_{2,} \mathrm{CH}_{4,}$ etc \\
\hline Cell efficiency & $75 \%$ & $70 \%$ & $85 \%$ & $80 \%$ & $85 \%$ \\
\hline
\end{tabular}

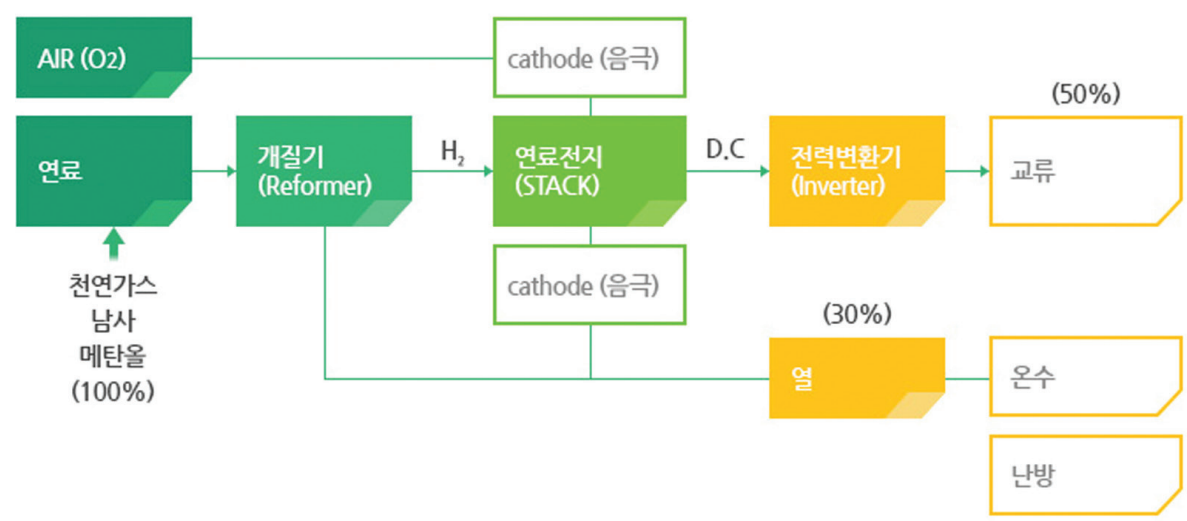

Fig. 2. System configuration based on fuel celli3)

하지만 기존 $\mathrm{SOFC}$ 의 높은 작동온도는 장점인 동시에 단점으로 다가오게 된다. $800 \sim 1000{ }^{\circ} \mathrm{C}$ 의 작동온도는 연료전지 구성요소간의 열적팽창계수 차이로 인한 내구
성의 한계, 전극물질로써 사용 가능한 물질의 제한, 고온 작동환경 유지에 필요한 높은 비용, 구성요소간의 화학적 반응 등의 문제를 야기할 수 있다. 이러한 문제를 해결하

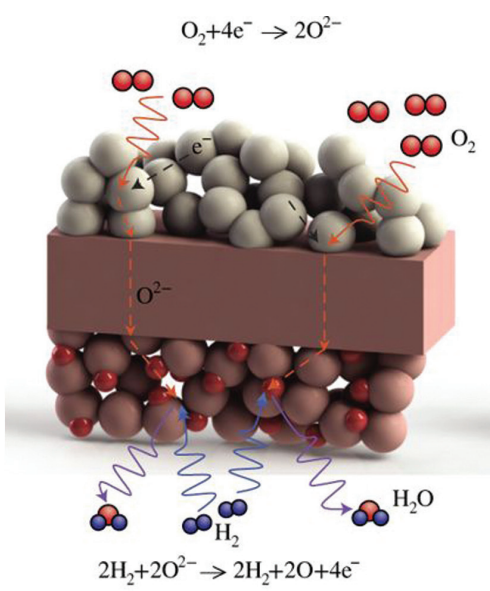

Solid oxide fuel cell (SOFC)

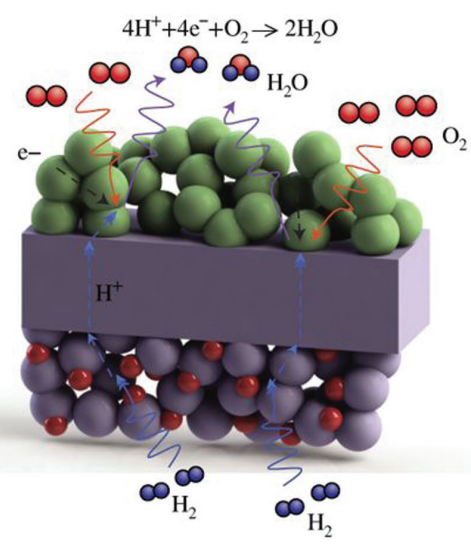

$2 \mathrm{H}_{2} \rightarrow 4 \mathrm{H}^{+}+\mathrm{e}^{-}$

Protonic ceramic fuel cell (PCFC)

Fig. 3. Comparison of Solid Oxide Fuel Cells and Protonic Ceramic Fuel Cells ${ }^{18)}$ 
기 위하여 $650{ }^{\circ} \mathrm{C}$ 이하에서 작동되는 저온형 고체산화물 연료전지(LT-SOFC)에 대한 연구가 진행되고 있지만, 저온에서의 낮은 산소이온의 이온전도성과 이로 인한 낮 은 성능은 고체산화물 연료전지의 새로운 문제점으로 꼽 힌다. ${ }^{14-17)}$

한편 양성자 전도성 고체산화물(Protonic ceramic oxide, $\mathrm{PCO}$ )을 이용한 양성자 전도성연료전지 (Protonic ceramic fuel cell, $\mathrm{PCFC}$ )는 새로운 저온형 연료전지로 써 최근 많은 관심을 받고 있다. 1960년대, 고체산화물의 수증기 및 수소 용해성에 대한 연구를 통하여 양성자가 minority charge carrier로써 존재하는 것으로 보인다 는 것을 보여주는 연구가 발표된 이후 ${ }^{19)} 1980$ 년대 초, $\mathrm{SrCeO}_{3}$ 및 $\mathrm{BaCeO}_{3}$ 과 같은 페로브스카이트 물질에서 양 성자 전도현상을 발견하였다. ${ }^{20,21)}$ 산소음이온에 비해서 작은 양성자는 양성자 전도에 필요한 활성화 에너지가 산 소음이온의 활성화 에너지의 절반가량이므로 $(0.4$ $0.6 \mathrm{eV}) 650{ }^{\circ} \mathrm{C}$ 이하의 저온에서도 충분한 이온전도 반 응이 일어날 것으로 예상된다. ${ }^{22)} \mathrm{PCFC}$ 에서는 다음과 같 은 반응들이 일어나는 것으로 알려져 있다.

$$
\begin{aligned}
& 2 \mathrm{H}_{2} \rightarrow 4 \mathrm{H}^{+}+4 \mathrm{e}^{-}(\text {연료극, 음극 }) \\
& \left.4 \mathrm{H}^{+}+\mathrm{O}_{2}+4 \mathrm{e}^{-} \rightarrow 2 \mathrm{H}_{2} \mathrm{O} \text { (공기극, 양극 }\right) \\
& 2 \mathrm{H}_{2}+\mathrm{O}_{2} \rightarrow 2 \mathrm{H}_{2} \mathrm{O} \text { (전체 반응) }
\end{aligned}
$$

연료극으로 공급된 수소는 양성자와 전자로 분리되어 각각 전해질과 도선을 따라 이동하게 된다. 전해질을 통 과한 양성자는 공기극에서 산소와 반응하여 물을 형성하 게 된다. 기존의 $\mathrm{SOFC}$ 의 전기화학 반응이 연료극에서 물이 생성되는 현상을 보여주는 것과 달리, $\mathrm{PCFC}$ 의 경우 전기화학적 반응을 통해 생성되는 물이 연료가 공급되는 연료극 쪽이 아닌 공기극에서 생성되기 때문에 연료가 희 석되는 효과를 베재할 수 있어 연료를 더욱 효과적으로 사용할 수 있다. ${ }^{23)}$ 이러한 특징을 통하여 $\mathrm{PCFC}$ 는 저온형 고체산화물 연료전지의 새로운 대안으로써 주목받기 시 작하였다. 이 글에선 양성자 전도성 고체산화물과 이를 이용한 $\mathrm{PCFC}$ 의 개발과정에 대해서 알아보도록 하겠다.

\section{2. 본론}

\section{1 고체산화물에서의 양성자 전도과정}

양성자 전도성 고체산화물에서의 양성자 전도과정을 설명하기 위해서는 우선 oxygen vacancy가 gas phase 로부터 공급된 oxygen로 채워 electron hole을 형성하 는 산화반응을 살펴보아야 한다. ${ }^{24-26)}$ 해당 반응은 다음과 같은 Kroger-Vink notation으로 표현이 가능하다

$$
\frac{1}{2} O_{2}+V_{o} \leftrightarrow O_{o}^{x}+2 h . \quad K_{o}=\frac{\left[O_{o}^{x}\right]\left[h^{\cdot}\right]^{2}}{\left(p_{O_{2}}\right)^{1 / 2}\left[V_{o}^{\cdot \cdot}\right]}
$$

상기 식에서 표현하였듯, oxygen이 oxygen vacancy 와 반응하여 vacancy를 oxygen으로 채우게 되고, electrical hole이 2개 형성되게 된다. 전도할 양성자가 없을 경우 해당 반응이 일어나지만 양성자 전도성이 있는 물질이 가습환경 하에 있을 경우, 이와 같은 수화반응이 일어나게 된다.

$\mathrm{H}_{2} \mathrm{O}+\mathrm{V}_{o} \cdot \mathrm{O}_{o}^{x} \leftrightarrow 2 O H_{o} \quad K_{w}=\frac{\left[O H_{o}^{\cdot}\right]^{2}}{p_{\mathrm{H}_{2} \mathrm{O}}\left[\mathrm{O}_{o}^{x}\right]^{2}\left[V_{o}^{\cdot \cdot}\right]}$

위 반응식에 따르면 gas phase에서 공급된 수증기가 수산화이온과 양성자로 분해되고, 이를 통해 형성된 수산 화이온은 oxygen vacancy를, 양성자는 격자 내의 산소 와 공유결합을 만들어 두 번째 protonic defect를 형성한 다. 정리하자면 수증기와 oxygen vacancy의 반응을 통 해 2 개의 수산화이온이 형성되고, 결과적으로 2 개의 protonic defect가 형성된다. 이 반응은 일종의 산-염기 반응이며, 산화-환원 반응성이 낮은 물질의 경우 위 반 응이 유일하게 일어날 것으로 예상된다. 하지만 반대의 경우, 산화반응과 수화반응이 동시에 일어나게 되어 다음 과 같은 반응이 일어난다.

$$
\begin{gathered}
H_{2} O+2 O_{o}^{x}+2 h^{\cdot} \leftrightarrow 2 O H_{o}^{\cdot}+\frac{1}{2} O_{2} \\
K_{w / o}=\frac{\left(p_{O_{2}}\right)^{1 / 2}\left[O H_{o}\right]^{2}}{p_{H_{2} O}\left[O_{o}^{x}\right]\left[h^{\cdot}\right]^{2}}=\frac{K_{w}}{K_{o}}
\end{gathered}
$$

위 반응은 수소화반응이라고 불리며, hole-전도성을 


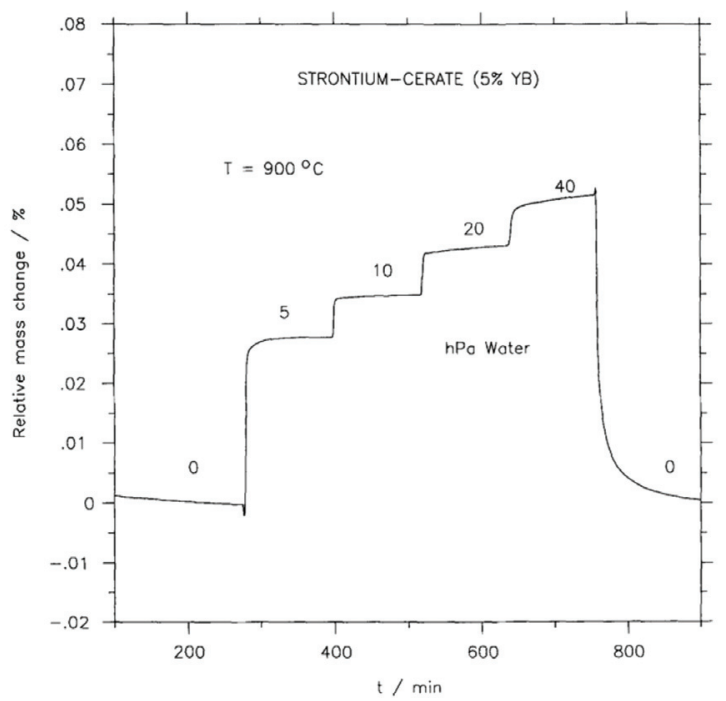

Fig. 4. Weight change depending on the water vapor pressure ${ }^{27}$

가지는 양극물질의 경우 oxygen vacancy가 없는 경우 에도 proton incorporation이 가능하다. 위 반응들을 종 합하면 수증기분압이 증가함에 따라 우세한 반응이 수화 반응에서 수소화반응으로 변화하는 것을 알 수 있다. 따 라서 물질의 양성자전도성을 측정 및 계산할 때에는 측정 조건에 따라 우세한 반응이 바뀌는 이러한 경향에 대해서 고려해야 한다.

이와 같은 protonic defect의 형성반응을 위해서는 표 면에서의 물의 흡수가 필수적이다. 이는 무게증가를 동반 하는 특징을 가지기 때문에, TGA를 통하여 온도 및 수증 기압에 따른 무게변화를 관찰한다면 위 수화 및 수소화 반응의 평형상수를 계산할 수 있다. 이렇게 계산된 평형 상수는 Arrhenius plot을 통하여 각 측정환경에 따른 protonic defect 형성 반응의 엔탈피 및 엔트로피 변화를 계산할 수 있다. ${ }^{27)}$

페로브스카이트 산화물에서의 양성자 확산은 크게 두 단계로 이루어져 있다고 보고되었다. 첫 번째는 $\mathrm{OH}$ 결합 이 인접한 산소로 향하는 방향전환 단계이다. 이 단계를 통하여 양성자 전달에 필요한 에너지 장벽이 줄어들게 되 고 양성자는 수소결합을 끊고 전달 될 수 있게 된다. 두 번째 단계는 양성자 이동 단계로, 약해진 기존의 수소결 합을 끓고 인접한 산소격자로 양성자가 이동하여 새로운

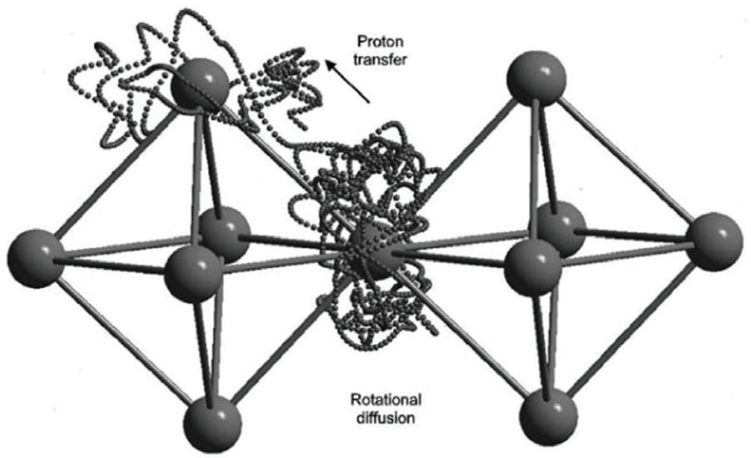

Fig. 5. The trace of a proton in a perovskite showing rotational diffusion and proton transfer ${ }^{28)}$

수소결합을 만드는 단계이다. 이런 방식을 통하여 양성자 는 양성자 전도성 세라믹 물질을 통해서 전도되게 된 다. ${ }^{22)}$ 현재 양성자 확산에 대한 동역학적 특성을 실험적 으로 얻고 이를 시각화시키는 연구가 진행되고 있다.

\section{2 양성자 전도성 세라믹 전해질 물질}

여러 가지 양성자 전도성 세라믹 물질들 가운데, $\mathrm{BaCeO}_{3}$ 혹은 $\mathrm{SrCeO}_{3}$ 를 기반으로 한 페로브스카이트 타 입의 산화물들은 가장 높은 양성자 전도성을 보여주는 것 으로 발표되었다. ${ }^{29)}$ 가장 높은 양성자 전도성능을 보여줌 에도 불구하고, 이러한 세라믹 물질들은 수증기나 이산화 탄소와 반응하여 분해되는 반응을 보여주어 안정성 면에 서 문제가 제기되었다. ${ }^{30)} \mathrm{BaCeO}_{3}$ 은 물과 반응하여 수산 화바륨과 산화세륨으로 분해되는 반응을 보여주었으며,

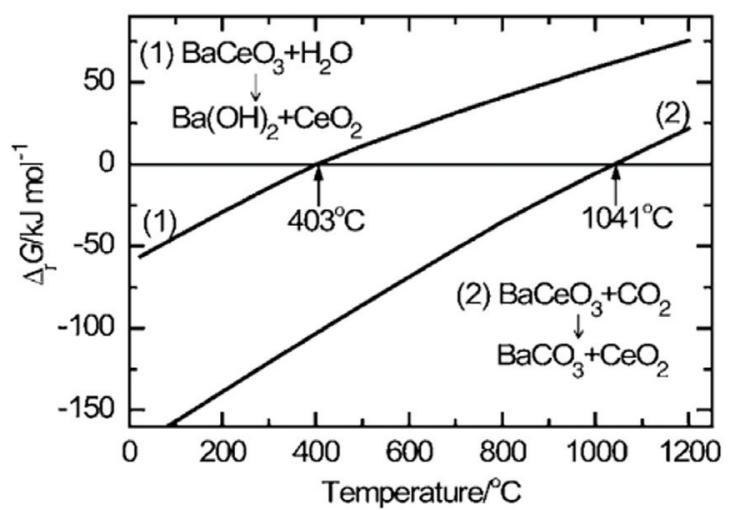

Fig. 6. Gibbs free energy change of hydration and carbonation reaction of $\mathrm{BaCeO}_{3}$ as function of temperature ${ }^{30}$ 


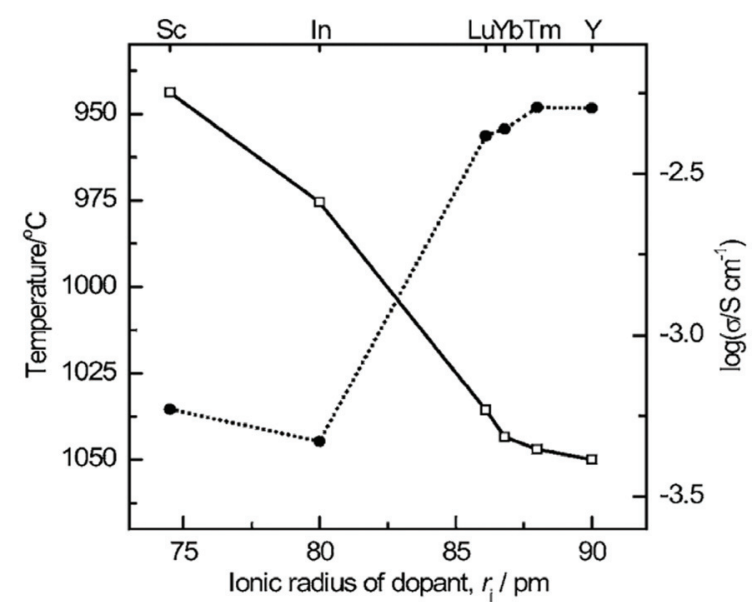

Fig. 7. $\mathrm{CO}_{2}-$ reaction temperature (squares) and the conductivity at $400{ }^{\circ} \mathrm{C}$ (circles) $)^{30}$

이산화탄소와 반응 시 탄산바륨과 산화세륨으로 분해되 는 반응을 보여주는 것으로 보고되었다. 위 반응들은 다 음과 같다.

$$
\begin{aligned}
& \mathrm{BaCeO}_{3}+\mathrm{CO}_{2} \rightarrow \mathrm{CeO}_{2}+\mathrm{BaCO}_{3} \\
& \mathrm{BaCeO}_{3}+\mathrm{H}_{2} \mathrm{O} \rightarrow \mathrm{CeO}_{2}+\mathrm{Ba}(\mathrm{OH})_{2}
\end{aligned}
$$

$\mathrm{BaCeO}_{3}$ 이 물과 반응하는 반응의 표준깁스자유에너지 변화는 약 $400{ }^{\circ} \mathrm{C}$ 내외에서 0 을 보여주었으며 그 이하의 온도에서는 음수를 보여준다. 반면 이산화탄소와의 반응 의 경우 약 $1000{ }^{\circ} \mathrm{C}$ 에서 음수의 자유에너지 변화를 보여 주어 높은 이산화탄소 부분압력 하에서 불안정할 것으로 보인다. 이에 B site의 세륨을 다른 삼가 이온으로 치환 하여 $\mathrm{BaCeO}_{3}$ 의 화학적 안정성을 향상시키는 연구가 진 행되었다. ${ }^{30)}$ 그 결과 세륨을 이트륨으로 치환할 경우 이 산화탄소와의 탄소화 반응이 일어나는 온도가 다른 원자 들과 치환된 화합물의 경우보다 더 높아질 뿐만 아니라 전도도 또한 향상되어 이산화탄소에 대한 화학적 안정성 향상 및 성능향상을 동시에 이루는 것을 확인하였다. ${ }^{30,31)}$

한편 $\mathrm{BaZrO}_{3}$ 계열의 양성자 전도성 세라믹 물질들은 앞서 언급한 $\mathrm{BaCeO}_{3}$ 계열의 세라믹 물질들의 문제점이 었던 이산화탄소에 대한 화학적 안정성이 상대적으로 뛰 어나 주목을 받고 있었다. 이는 지르코늄의 전기음성도가 세륨의 전기음성도보다 높고 지르코늄-산소 결합의 공 유원자가가 더 높기 때문으로 해석된다. 하지만 $\mathrm{BaZrO}_{3}$ 계열의 세라믹 물질들은 $\mathrm{BaCeO}_{3}$ 계열의 세라믹물질과 비교하였을 때 소결성이 떨어져 고밀도의 멤브레인을 형 성하기 힘들며 grain boundary에서 양성자 전도과정에

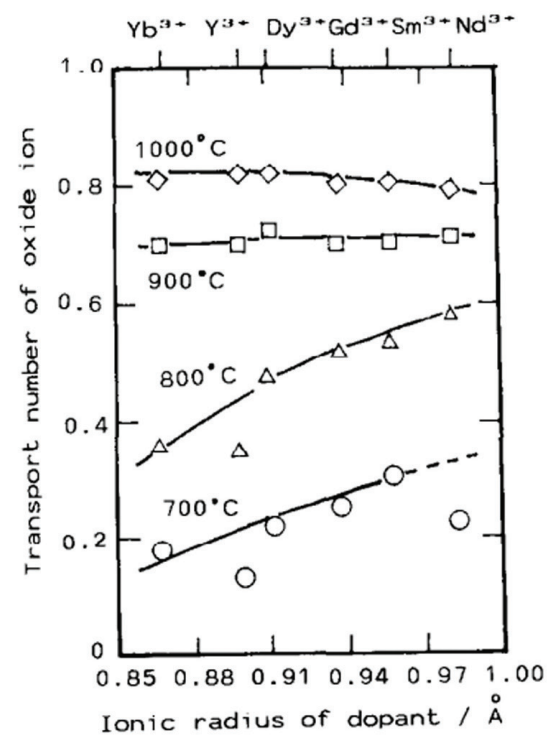

Fig. 8. Ionic transport number of proton and oxide ion as function of ionic radius of dopant ${ }^{31)}$ 
대한 높은 저항이 문제가 된다. ${ }^{32)}$ 이러한 현상들을 해결 하기 위하여 소량의 첨가물을 넣어주어 소결성을 높이거 나 펄스레이저 증착법(Pulsed laser deposition, PLD) 을 이용하여 성능을 향상시킨 국내외의 연구들이 보고되 고 있다. ${ }^{33-36)}$

한편 $\mathrm{BaCeO}_{3}$ 계열의 양성자 전도성 세라믹 물질과 $\mathrm{BaZrO}_{3}$ 계열의 양성자 전도성 세라믹물질이 각각 뛰어 난 전기화학적 성능과 높은 화학적 안정성이라는 특성을 각각 보이는 것이 여러 연구를 통해 규명되자, 이에 많은 연구자들은 높은 전도도를 가지는 동시에 이산화탄소에 노출되어도 뛰어난 안정성을 가지는 $\mathrm{BaCeO} 3-\mathrm{BaZrO} 3$ 고체혼합물에 주목하기 시작하였다. 별도의 2 차반응 없 이 균일하게 하나의 상을 만드는 것이 관찰된 $\mathrm{BZC}$ 고체 혼합물은 화합물 내의 지르코늄 함량이 높아짐에 따라 전도도는 감소하였으나 이산화탄소에 대한 화학적 안정 성은 향상되는 결과를 보여주었다. ${ }^{37)}$ 특히 지르코늄 함량 이 0.4 인 $\mathrm{BaCe}_{0.5} \mathrm{Zr}_{0.4} \mathrm{Y}_{0.1} \mathrm{O}_{3-\delta}$ 의 경우 이산화탄소에 노출 됨에도 별도의 부반응 없이 안정한 결과를 보여주었다.

앞서 언급하였듯 $\mathrm{BaCeO}_{3}$ 의 세륨을 $\mathrm{Nd}, \mathrm{Gd}, \mathrm{Sm}, \mathrm{Y}$, $\mathrm{Yb}$ 와 같은 삼가 이온으로 치환하게 되면 oxygen vacancy가 형성되게 되고 이를 통하여 이온전도성에 영 향을 줄 수 있다. ${ }^{30,31)}$ 한편 $\mathrm{SOFC}$ 에서 전해질로써 사용되 는 YSZ나 ceria 기반의 전해질을 대체하기 위해서는 저 온영역에서 기존의 전해질 물질보다 높은 이온전도성을 확보할 필요가 있었다. 이러한 관점에서, 삼가 이온을 이 용하여 양성자 전도성 세라믹 물질의 이온전도성을 향상 시키는 연구가 주로 이루어졌으며, 여러 이온들 중에서도 이트륨은 $\mathrm{BaCeO}_{3}$ 뿐만 아니라 $\mathrm{BaZrO}_{3}$ 의 전도도를 향상 을 보여주는 것을 보여주었다. ${ }^{38)}$ 이터븀 이온 또한 $\mathrm{BaCeO}_{3}$ 의 란탄족 이온들과 비교하였을 때 성능을 획기 적으로 향상시키는 것을 보여주었다. 흥미로운 점은 아직 정확한 이유는 알 수 없으나 이트륨과 이터붐을 각각 도 핑한 것 보다 두 이온을 동시에 co-doping 하였을 경우 더욱 향상된 성능을 보여주었으며, 특히 $450 \sim 750{ }^{\circ} \mathrm{C}$ 의 중저온 영역에서 기존의 YSZ나 GDC에 비해서 높은 이온전도도를 보여주었다. 정리하자면, 이트륨 및 이터 붐이 도핑된 $\mathrm{BaCeO}_{3}-\mathrm{BaZrO}_{3}$ 고체혼합물인 $\mathrm{BZCYYb}$

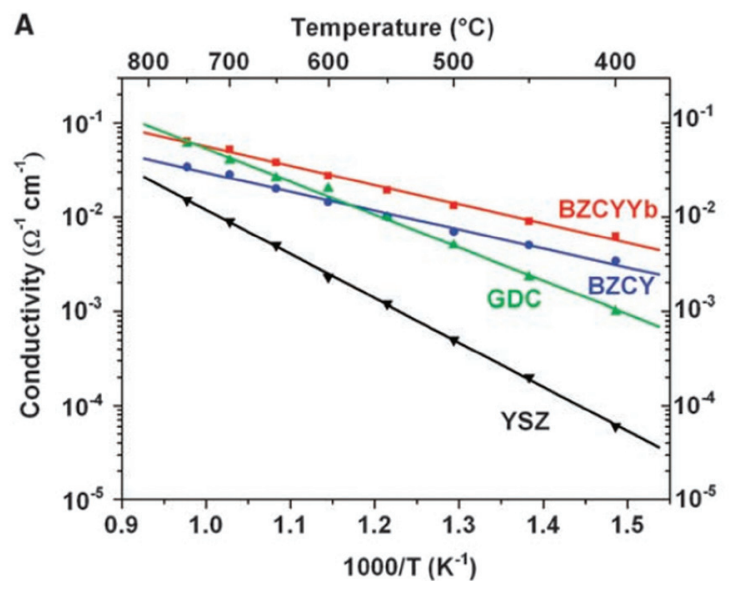

Fig. 9. Comparison of total ionic conductivity in the intermediate temperature ${ }^{38)}$

은 뛰어난 이온전도성과 높은 화학적 안정성을 가져 양성 자 전도성 세라믹 연료전지의 전해질로서 매우 유용한 물 질이라고 할 수 있다.

\section{3 양성자 전도성 세라믹 공기극 물질}

기존의 $\mathrm{SOFC}$ 시스템의 양극물질은 중저온 영역 (Intermedaite temperature, IT)에서의 전기화학반응 촉매로써의 성능이 낮아지는 문제점이 있었다. 이는 전해 질, 전극 그리고 공기의 경계(Triple phase boundary, $\mathrm{TPB})$ 에서만 산소의 환원반응이 일어나기 때문으로 알려 져있다. 이를 해결하기 위하여 혼합 이온 및 전자 전도체 (Mixed ionic and electronic conductor, MIEC)가 IT-

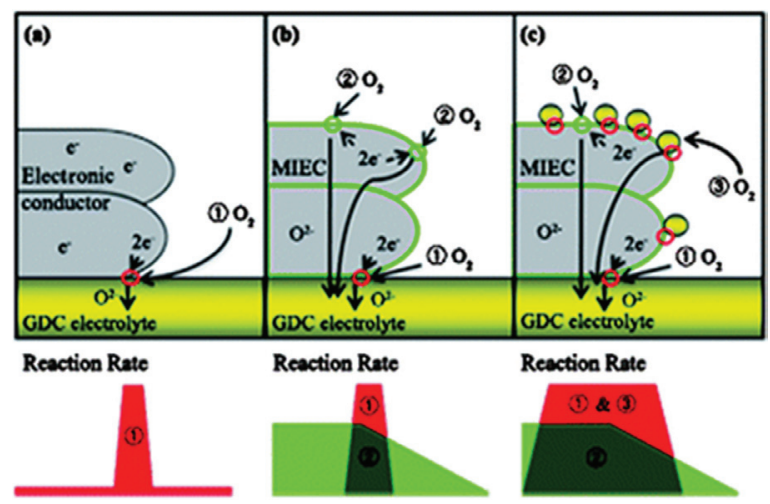

Fig. 10. Schematic of the oxygen reduction reaction at (a) electronic conductor, (b) MIEC and (c) MIEC-ionic conductor for SOFC ${ }^{44)}$ 

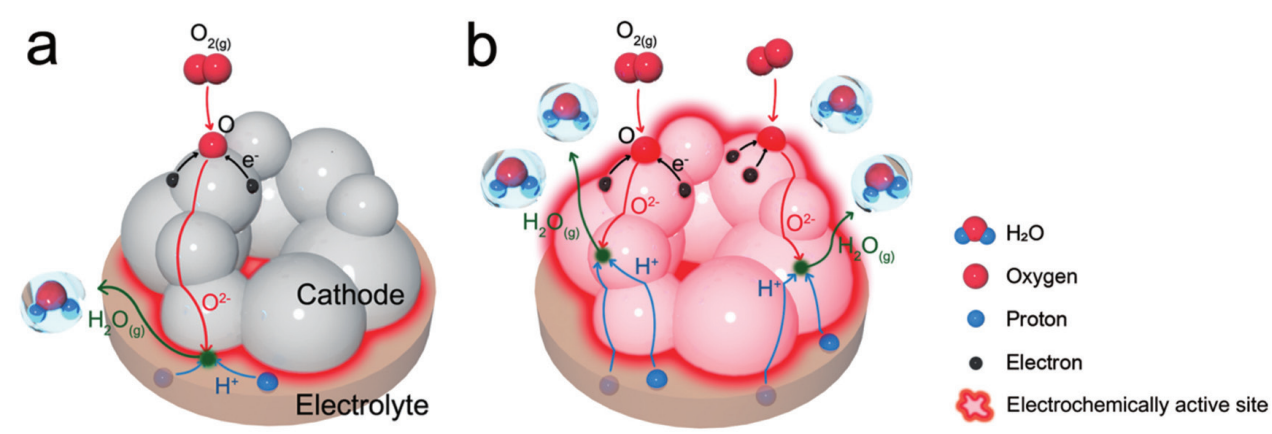

Fig. 11. (a) Schematic illustration of the water formation reaction at the PCFC cathode using (a) MIEC $\left(\mathrm{O}^{2-} / \mathrm{e}^{-}\right)$and (b) $\mathrm{TCO}\left(\mathrm{H}^{+} / \mathrm{O}^{2-} / \mathrm{e}^{-}\right)^{45)}$

$\mathrm{SOFC}$ 의 공기극 물질로 주로 사용되었다. ${ }^{39-42)}$ 이를 통하 여 TPB 뿐만 아니라 전극과 공기가 만나는 표면 또한 전 기화학적으로 활성화되어 중저온 영역에서도 우수한 전 자전도성 및 산소환원 반응이 일어나 높은 성능을 확보할 수 있었다. ${ }^{43)}$

하지만 양성자 전도성 전해질에 기반한 $\mathrm{PCFC}$ 에서 낮 은 양성자 전도성을 가진 $\mathrm{MIEC}$ 물질들은 초기의 $\mathrm{SOFC}$ 공기극 촉매들이 그랬던 것처럼 전기화학적 반응이 일어 나는 표면적이 제한되게 된다. SOFC의 효율적인 구동을 위하여 MIEC를 전극으로 사용하였던 것처럼, 효율적으 로 $\mathrm{PCFC}$ 를 구동하기 위해서는 공기극 물질이 산소 음이 온, 전자 뿐만 아니라 양성자에 대한 전도특성을 가져야 만 한다. 이와 같은 성질을 가지는 물질을 삼중 전도성 산화물(Triple conducting oxide, TCO)라고 하며 이들 은 $\mathrm{MIEC}$ 가 $\mathrm{SOFC}$ 에서 그랬던 것처럼 $\mathrm{PCFC}$ 의 공기극에 서 전기화학적으로 활성된 표면을 확장시킨다고 보고되 었다. ${ }^{45}$

그럼에도 불구하고 $\mathrm{TCO}$ 의 체계적인 연구 및 개발은 양 성자 전도특성의 규명이 쉽지 않다는 단점으로 인하여 제 한되고 있다. 기존의 양성자 전도성 전해질 물질의 경우 농도셀에 대한 $\mathrm{OCV}$ 를 비교하여 각각의 물질이 가지는 양성자 전도특성을 비교할 수 있다. 하지만 $\mathrm{TCO}$ 의 경우 전자전도성이 워낙 크기 때문에 기존의 방법을 통하여 양 성자 전도특성을 구분하기가 쉽지 않다. 거기에 양성자뿐 만 아니라 산소이온과 전자의 전도가 동시에 공기극 전극 의 성능에 영향을 주기 때문에 한 가지 특성만 특정지어 구분하고 분석하는 것은 매우 복잡하다. 그럼에도 불구하
고 많은 연구진들이 $\mathrm{PCFC}$ 시스템의 성능을 최대한 향상 시키기 위하여 많은 연구를 진행하고 있다.

$\mathrm{Ba}_{0.5} \mathrm{Sr}_{0.5} \mathrm{Co}_{0.8} \mathrm{Fe}_{0,2} \mathrm{O}_{3-\delta}(\mathrm{BSCF})$ 나 $\mathrm{PrBaCO}_{2} \mathrm{O}_{5+\delta}(\mathrm{PBCO})$ 와 같은 대표적인 $\mathrm{MIEC}$ 물질들은 높은 수화 특성을 나타 내었고 이는 해당 전극물질들의 oxygen vacancy가 뛰어 난 수화특성과 관계가 있음을 의미하였다. ${ }^{46)} \mathrm{LnBaCoO}_{5+\delta}$ $(\mathrm{Ln}=\mathrm{Pr}, \mathrm{Sm}, \mathrm{Gd})$ 의 이중층 페로브스카이트 공기극을 가진 단일셀은 $700{ }^{\circ} \mathrm{C}$ 에서 $266 \sim 382 \mathrm{~mW} \mathrm{~cm}{ }^{-2}$ 의 최대
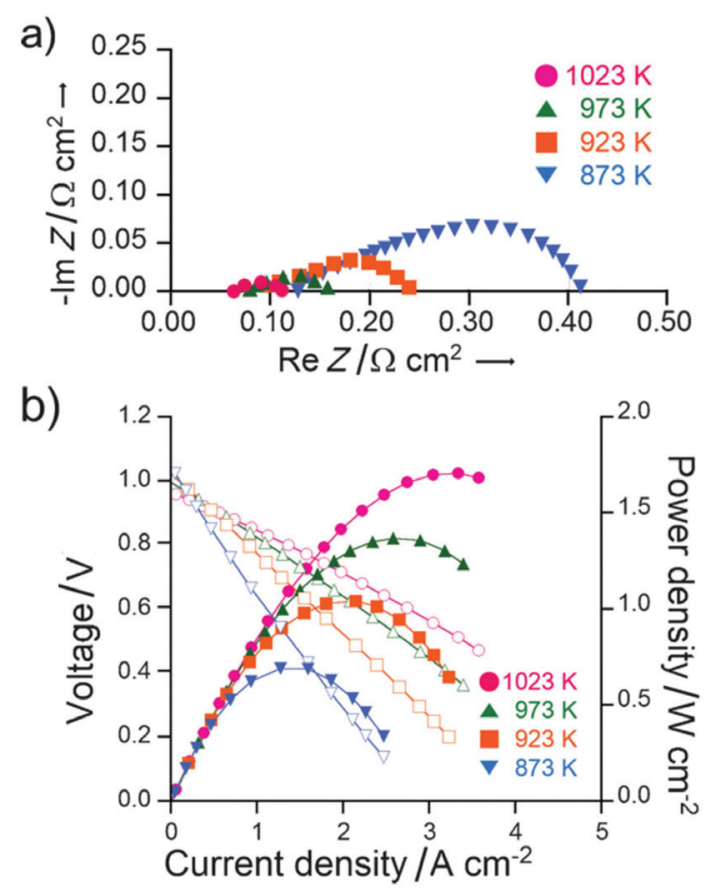

Fig. 12. (a) Impedance spectra of the single cell (NBSCF/BZ$\mathrm{CYYb} / \mathrm{NiO}-\mathrm{BZCYYb}$ ), and (b) $1-\mathrm{V}$ curve and corresponding power density curve. ${ }^{45)}$ 

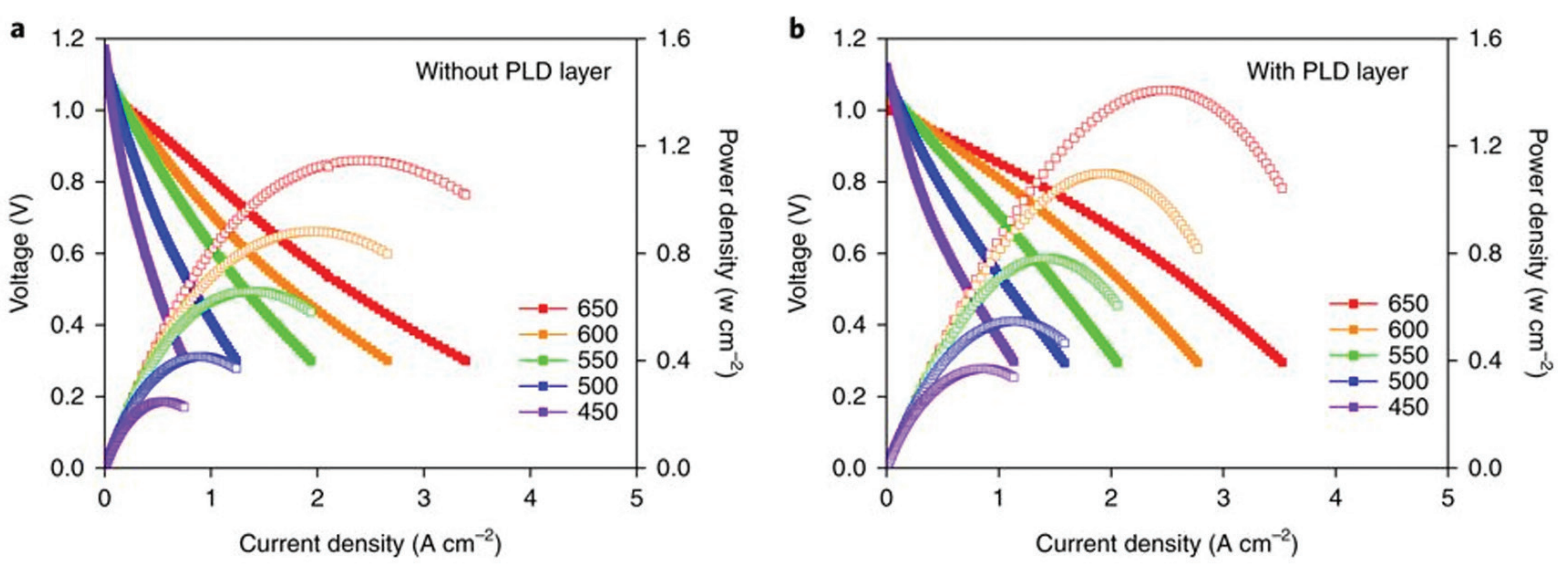

Fig. 13. I-V curve and corresponding power density curve of the single cell (PBSCF/BZCYYb/NiO-BZCYYb) (a)without PLD layer, and (b)with PLD layer. ${ }^{52)}$

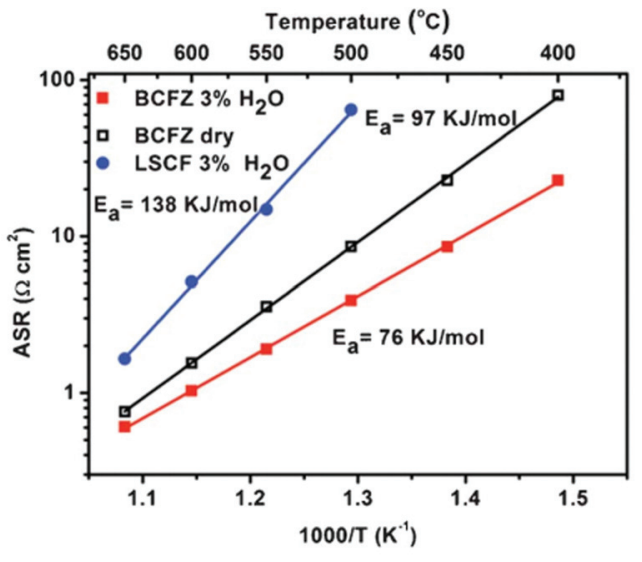

Fig. 14. Area specific resistance of BCFZ as function of temperature ${ }^{55}$

출력밀도를 보여주었다. ${ }^{47-49)}$ 이러한 가능성에 힘입어 여 러 가지 전이금속을 이중층 페로브스카이트 전극물질에 도핑하여 더욱 높은 전기화학적 성능과 화학적 안정성의 향상을 위한 후속연구가 보고되었다. 예를 들어 $\mathrm{PCFC}$ 의 공기극 전극으로써 이중층 페로브스카이트 전극물질이 가지는 가능성에 $\mathrm{Sr}^{2+}$ 이온을 $\mathrm{A}^{\prime}$ 위치의 바륨과 치환하여 $\mathrm{SOFC}$ 공기극의 성능을 향상시키는 연구결과를 더하여 더 낮은 분극저항과 $520 \sim 533 \mathrm{~mW} \mathrm{~cm}$ 의 향상된 성 능이 발표되었다. ${ }^{50,51)} \mathrm{Fe}$ 이온을 도핑 하는 것 또한 향상 된 전기화학적 성능을 보여주는 것으로 보고되어있으며, 이 이온들을 동시에 치환한 $\mathrm{NdBa}_{0.5} \mathrm{Sr}_{0.5} \mathrm{Co}_{1.5} \mathrm{Fe}_{0.5} \mathrm{O}_{5+\delta}$ $(\mathrm{NBSCF})$ 는 $600{ }^{\circ} \mathrm{C}$ 에서도 낮은 분극저항과 $690 \mathrm{~mW}$ $\mathrm{cm}^{-2}$ 의 매우 높은 성능을 보여주었다. ${ }^{45)} \mathrm{PrBa}_{0.5} \mathrm{Sr}_{0.5} \mathrm{Co}_{1.5}$ $\mathrm{Fe}_{0.5} \mathrm{O}_{5+\delta}$ (PBSCF) 의 경우 $600{ }^{\circ} \mathrm{C}$ 에서도 $890 \mathrm{~mW}$ $\mathrm{cm}^{-2}$ 의 높은 성능을 보여주었다. ${ }^{52)}$ 추가적으로 이 연구 에서는 PLD 과정을 통해 향상된 공기극과 전해질 사이의 접촉을 기반으로 $1098 \mathrm{~mW} \mathrm{~cm}$ 의 더욱 향상된 전기화 학적 성능을 발표하였다. $\mathrm{BaCeO}_{3}$ 의 B site에 $\mathrm{Pr}$ 과 $\mathrm{Gd}$ 와 같은 삼가 란탄족 이온을 치환할 경우, 습한 대기 하에서 $\mathrm{p}$-type의 전도성을 가지는 것을 확인되었고, 이 반응에 는 약간의 프로톤 특성이 영향을 주는 것이 보고되었 다. ${ }^{53,54)}$ 코발트나 철과 같은 전이금속 양이온을 치환한 $\mathrm{BaCO}_{0.4} \mathrm{Fe}_{0.4} \mathrm{Zr}_{0,2} \mathrm{O}_{3-\delta}$ 은 높은 안정성을 보여줌과 동시에 $\mathrm{LSCF}$ 공기극 전극의 활성화 에너지 $\left(138 \mathrm{~kJ} \mathrm{~mol}^{-1}\right)$ 보다 현저히 낮은 $76 \mathrm{~kJ} \mathrm{~mol}^{-1}$ 의 활성화 에너지를 보여주었 다. ${ }^{55)}$ 최근 발표된 $\mathrm{BaCO}_{0.4} \mathrm{Fe}_{0.4} \mathrm{Zr}_{0,1} \mathrm{Y}_{0.1} \mathrm{O}_{3-\delta}$ (BCFZYO.1) 공기극 전극의 경우 $500{ }^{\circ} \mathrm{C}$ 에서도 $455 \mathrm{~mW} \mathrm{~cm}$-2의 우수 한 최대 출력밀도를 가지는 것으로 알려져 있다. ${ }^{56)}$ 이 외 에도 단위셀 당 $20.8 \mathrm{~W}$ 의 성능을 보이는 $5 \times 5 \mathrm{~cm}^{2}$ 의 대 면적 셀이 보고된 바 있다. ${ }^{57)}$

\section{3. 결론}

양성자 전도성 세라믹 물질을 활용한 연료전지는 기존 의 고체산화물 연료전지가 해결해야 하는 중저온에서의 높은 성능이라는 문제점을 해결할 수 있는 새로운 돌파구 
이다. 양성자 전도성 세라믹물질은 산소 이온에 비해 더 낮은 에너지만으로 전도가 가능한 양성자를 전도시켜 이 온전도성을 향상시키므로 연료전지의 구동 온도를 중저 온으로 낮출 수 있다. 이를 바탕으로 양성자 전도성 세라 믹 물질의 특성을 극대화시키기 위한 연구가 진행되어 국 내외 여러 연구진으로부터 향상된 전해질 및 공기극이 발 표되고 있다. 하지만 양성자, 산소이온, 전자를 동시에 전도하는 삼중 전도 산화물의 연구의 경우 각각의 전도특 성을 모두 개별절적으로 분리하여 분석하는 것은 매우 복 잡하기 때문에 삼중 전도 산화물의 체계적인 연구에 대해 서는 앞으로 더 많은 연구가 필요할 것으로 보인다.

\section{참고문헌}

1. M. Winter, and R. J. Brodd, "What are batteries, fuel cells, and supercapacitors?" Chem. Rev. 104 [10] 4245 - 4270 (2004)

2. I.K. Kapdan, and F. Kargi. "Bio-hydrogen production from waste materials" Enzyme Microb. Technol. 38 [5] 569-582 (2006)

3. R. O'Hayre, S.-W. Cha, W. Colella and F.B. Prinz "Fuel cell fundamentals" $3^{\text {rd }}$ edition, pp 3-18, Wiley 2016

4. G. Pepermans, J. Driesen, D. Haeseldonckx, R. Belmans and W. D'haeseller. "Distributed generation: definition, benefits and issues" Energy Policy. 33 [6] 787-798 (2005)

5. M.C. Williams, J.P. Strakey and S.C. Singhal. "U.S. distributed generation fuel cell program" J. Power Sources. 131 [1-2] 79-85 (2004)

6. S. Sengodan, S.Choi, A. Jun, T. H. Shin, Y.-W.Ju, H. Y. Jeong, J. Shin, J. T. S. Irvine, and G.Kim, "Layered oxygen-deficient double perovskite as an efficient and stable anode for direct hydrocarbon solid oxide fuel cells." Nat. Mater. 14, 205-209. (2014)

7. S. Choi, S. Yoo, J. Kim, S. Park, A. Jun, S. Sengodan, J.Kim, J. Shin, H. Y. Jeong, Y. Choi, G. Kim, and M. Liu, Highly efficient and robust cathode materials for low-temperature solid oxide fuel cells: $\operatorname{PrBa}_{0.5} \mathrm{Sr}_{0.5} \mathrm{CO}_{2-}$ ${ }_{x} \mathrm{Fe}_{\mathrm{x}} \mathrm{O}_{5+\delta}$. Sci. Rep. 3, 2426. (2013)

8. M. Mogensen, K. V. Jensen, M.J. Jø rgensen, and S. Primdahl, "Progress in understanding SOFC electrodes." Solid State Ionics. 150 [1-2] 123-129 (2002)
9. S. Park, J. M. Vohs, and R.J.Gorte, "Direct oxidation of hydrocarbons in a solid-oxide fuel cell" Nature. 404, $265-267$ (2000)

10. S. Tao, and J. T. S. Irvine, "A redox-stable efficient anode for solid-oxide fuel cells." Nat. Mater. 2, 320 323 (2003)

11. N. Q. Minh, "Ceramic Fuel Cells." J. Am.Ceram.Soc. 76 [3] $563-588$ (1993)

12. M. D. Gross, J.M.Vohs, and R.J.Gorte, "Recent progress in SOFC anodes for direct utilization of hydrocarbons." J. Mater. Chem. 17, 3071- 3077 (2007)

13. https://www.knrec.or.kr/energy/fuelcell_summary. aspx

14. B.C.H. Steele, "Material science and engineering: The enabling technology for the commercialisation of fuel cell systems" J. Mater.Sci. 36 [5] 1053-1068. (2001)

15. S. B. Adler, "Factors Governing Oxygen Reduction in Solid Oxide Fuel Cell Cathodes" Chem.Rev. 104 [10] 4791- 4844 (2004)

16. D. M. Bastidas, S.Tao, and J.T.S.Irvine, "A symmetrical solid oxide fuel cell demonstrating redox stable perovskite electrodes" J. Mater. Chem. 16, $1603-1605$ (2006)

17. E.D. Wachsman, and K.T. Lee, "Lowering the Temperature of Solid Oxide Fuel Cells." Science. 334 [6058] 935 - 939, (2011)

18. J. H. Shim, "Ceramics breakthrough." Nature Energy. 3, $168-169$ (2018)

19. S. Stotz and C. Wagner. "The solubility of water vapor and hydrogen in solid oxides" (in Ger.) Ber. Bunsenges. Phys. Chem. 70 [8] 781-88 (1966)

20. H. Iwahara, T. Esaka, H. Uchida and N. Maeda, "Proton conduction in sintered oxides and its application to steam electrolysis for hydrogen production” Solid State Ionics. 3-4, 359-363 (1981)

21. H. Iwahara, "Proton conducting ceramics and their applications" Solid State Ionics. 86 - 88, 9-15 (1996)

22. K.D. Kreuer, "Proton Conductivity: Materials and Applications" Chem. Mater. 8 [3] 610-641 (1996)

23. Y. Matsuzaki, Y. Tachikawa, T. Somekawa, T. Hatae, H. Matsumoto, S. Taniguchi and K. Sasaki, "Effect of proton-conduction in electrolyte on electric efficiency of multi-stage solid oxide fuel cells" Sci. Rep. 5, 12640 (2015)

24. D. Poetzsch, R. Merkle and J. Maier, "Proton uptake in the $\mathrm{H}^{+}$-SOFC cathode material $\mathrm{Ba}_{0.5} \mathrm{Sr}_{0.5} \mathrm{Fe}_{0.8} \mathrm{Zn}_{0.2}$ $\mathrm{O}_{3-\delta}$ : transition from hydration to hydrogenation with increasing oxygen partial pressure" Faraday Discuss. 
182, 129-143 (2015)

25. R. Zohourian, R. Merkle and J. Maier, "Proton uptake into the protonic cathode material $\mathrm{BaCo}_{0.4} \mathrm{Fe}_{0.4} \mathrm{Zr}_{0.2} \mathrm{O}_{3-\delta}$ and comparison to protonic electrolyte materials" Solid State Ionics. 299, 64-69 (2016)

26. D. Poetzsch, R. Merkle and J. Maier, "Stoichiometry Variation in Materials with Three Mobile CarriersThermodynamics and Transport Kinetics Exemplified for Protons, Oxygen Vacancies, and Holes" Adv. Funct. Mater. 25 [10] 1542-1557 (2015)

27. F. Krug, T. Schober, and T. Springer, "In situ measurements of the water uptake in $\mathrm{Yb}$ doped $\mathrm{SrCeO}_{3-\delta}$ "Solid State Ionics. 81 [1-2] 111-118 (1995)

28. G. Seifert, S. Hazebroucq and W. Münch, "Quantum Molecular Dynamic Simulation of Proton conducting Materials"; pp 437-452 in Device and Materials Modeling in PEM Fuel Cells. Ed. by S. J. Paddison and K. S. Promislow, Springer, 2009

29. T. Norby and Y. Larring "Concentration and transport of protons in oxides" Curr. Opin. Solid State Mater. Sci. 2, [5] 593-599 (1997)

30. H. Matsumoto, Y. Kawasaki, N. Ito, M. Enoki and T. Ishihara, "Relation Between Electrical Conductivity and Chemical Stability of $\mathrm{BaCeO}_{3}$-Based Proton Conductors with Different Trivalent Dopants" Electrochem. Solid-State Lett. 10 [4], B77-B80. (2007)

31. H. Iwahara, T. Yajima and H. Ushida "Effect of ionic radii of dopants on mixed ionic conduction $\left(\mathrm{H}^{+}+\mathrm{O}^{2-}\right)$ in $\mathrm{BaCeO}_{3}$-based electrolytes" Solid State Ionics, 70-71, 267-271 (1994)

32. K. D. Kreuer, "Aspects of the formation and mobility of protonic charge carriers and the stability of perovskite-type oxides" Solid State Ionics. 125, [1-4] 285- 302 (1999)

33. Z. Sun, E. Fabbri, L. Bi and E. Traversa, "Lowering grain boundary resistance of $\mathrm{BaZr}_{0.8} \mathrm{Y}_{0.2} \mathrm{O}_{3-\delta}$ with $\mathrm{LiNO}_{3}$ sintering-aid improves proton conductivity for fuel cell operation" Phys. Chem. Chem. Phys. 13, 7692-7700 (2011)

34. D. Pergolesi, E. Fabbri, A. D'Epifanio, E. Di Bartolomeo, A. Tebano, S. Sanna, S. Licoccia, G. Balestrino and E. Traversa, "High proton conduction in grain-boundary-free yttrium-doped barium zirconate films grown by pulsed laser deposition" Nat. Mater. 9. 846-852 (2010)

35. K. Bae, S. M. Choi, J. Hwang, J. -W. Son and J. H. Shim, "Proton Conduction in Highly Textured
$\mathrm{Y}: \mathrm{BaZrO}_{3}$ and $\mathrm{Y}: \mathrm{BaZrCeO}_{3}$ Thin Films Fabricated by Pulsed Laser Deposition” ECS Transactions, 45 [1] 129-133 (2012)

36. K. Bae, D. Y. Jang, H. Jung, J. W. Kim, J.-W. Son, and J. H. Shim "Micro-Protonic Ceramic Fuel Cells with $\mathrm{Y}: \mathrm{BaZrO}_{3}$ Electrolyte Prepared by Pulsed Laser Deposition (PLD)" ECS Transactions, 57 [1] 935-938 (2013)

37. K. Katahira, Y. Kohchi, T. Shimura and H. Iwahara, "Protonic conduction in $\mathrm{Zr}$-substituted $\mathrm{BaCeO}_{3}$ ", Solid State Ionics, 138 [1-2] 91-98 (2000)

38. L. Yang, S. Wang, K. Blinn, M. Liu, Z, Liu, Z. Cheng and M. Liu, "Enhanced Sulfur and Coking Tolerance of a Mixed Ion Conductor for SOFCs: $\mathrm{BaZr}_{0,1} \mathrm{Ce}_{0.7} \mathrm{Y}_{0.2-}$ ${ }_{x} \mathrm{Yb}_{\mathrm{x}} \mathrm{O}_{3-\mathrm{d}^{"}}$ Science, 326 [5949] 126-129 (2009)

39. G. Kim, S. Wang, A. J. Jacobson, L. Reimus, P.Brodersen and C. A. Mims, "Rapid oxygen ion diffusion and surface exchange kineticsin $\mathrm{PrBaC}_{2} \mathrm{O}_{5+x}$ with a perovskite related structure and ordered A cations." J. Mater. Chem. 17 [24] 2500-2505 (2007)

40. A. J. Jacobson, "Materials for Solid Oxide Fuel Cells." Chem.Mater. 22 [3] 660-674 (2010)

41. A. Tarancon, S. J. Skinner, R. J. Chater, F. Hernandez-Ramarez and J. A. Kilner, "Layered perovskites as promising cathodes for intermediate temperature solid oxide fuel cells." J. Mater. Chem. 17, 3175 - 3181. (2007)

42. J.-H. Kim, A. Manthiram, "Layered $\mathrm{LnBaCO}_{2} \mathrm{O}_{5+\delta}$ Perovskite Cathodes for Solid Oxide Fuel Cells: An Overview and Perspective." J. Mater.Chem.A. 3, $24195-24210$ (2015)

43. W. Jung, K. L. Gu, Y. Choi and S. M. Haile, "Robust nanostructures withexceptionallyhighelectrochemical reaction activity for high temperature fuel cell electrodes" Energy Environ. Sci. 7, 1685-1692 (2014)

44. J. Kim, W. Seo, J. Shin, M. Liu and G. Kim, "Composite cathodes composed of $\mathrm{NdBa}_{0.5} \mathrm{Sr}_{0.5} \mathrm{CO}_{2} \mathrm{O}_{5+\delta}$ and $\mathrm{Ce}_{0.9} \mathrm{Gd}_{0.1} \mathrm{O}_{1,95}$ for intermediate-temperature solid oxide fuel cells", J. Mater. Chem. A, 1, 515 - 519 (2013)

45. J. Kim, S. Sengodan, G. Kwon, D. Ding, J. Shin, M. Liu and G. Kim "Triple-Conducting Layered Perovskites as Cathode Materials for ProtonConducting Solid Oxide Fuel Cells" ChemSusChem 7 [10] 2811- 2815 (2014)

46. A. Grimaud, F. Mauvy, J. M. Bassat, S. Fourcade, L. Rocheron, M. Marrony and J. C. Grenier, "Hydration Properties and Rate Determining Steps of the Oxygen Reduction Reaction of Perovskite-Related Oxides as 
$\mathrm{H}^{+}$-SOFC Cathodes" J. Electrochem. Soc. 159 [6] B683-B694 (2012)

47. B. Lin, S. Zhang, L. Zhang, L. Bi, H. Ding, X. Liu, J. Gao and $G$. Meng, "Prontonic ceramic membrane fuel cells with layered $\mathrm{GdBaCO}_{2} \mathrm{O}_{5+x}$ cathode prepared by gel-casting and suspension spray" J. Power Sources. 177 [2] 330-333 (2008)

48. B. Lin, Y. Dong, R. Yan, S. Zhang, M. Hu, Y. Zhou andG. Meng, "Insituscreen-printedBaZr $r_{0,1} \mathrm{Ce}_{0,7} \mathrm{Y}_{0,2} \mathrm{O}_{3-\delta}$ electrolyte-based protonic ceramic membrane fuel cells with layered $\mathrm{SmBaCO}_{2} \mathrm{O}_{5+\times}$ cathode" J. Power Sources 186 [2] 446-449 (2009)

49. M. Jin, X. Zhang, Y. Qiu and J. Sheng, "Layered $\mathrm{PrBaCo}_{2} \mathrm{O}_{5+\delta}$ perovskite as a cathode for protonconducting solid oxide fuel cells" J. Alloys Compd. 494 [1-2] 359-361 (2010)

50. H. Ding and X. Xue, "Proton conducting solid oxide fuel cells with layered $\mathrm{PrBa}_{0.5} \mathrm{Sr}_{0.5} \mathrm{CO}_{2} \mathrm{O}_{5+\delta}$ perovskite cathode" Int. J. Hydrogen Energy 35 [6], 2486-2490 (2010)

51. H. Ding, X. Xue, X. Liu and G. Meng, "A novel layered perovskite cathode for proton conducting solid oxide fuel cells" J. Power Sources 195 [3] 775-778 (2010)

52. S. Choi, C. J. Kucharczyk, Y. Liang, X. Zhang, I.

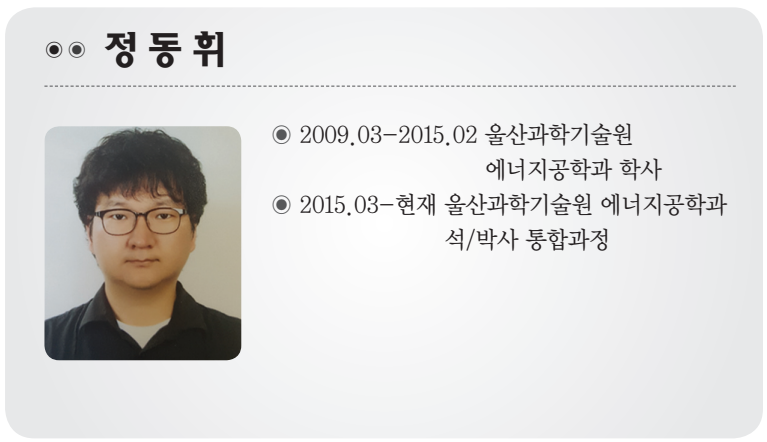

Takeuchi, H.-I. Ji and S. M. Haile, "Exceptional power density and stability at intermediate temperatures in protonic ceramic fuel cells" Nat. Energy. 3, 202-210 (2018)

53. R. Mukundan, P. K. Davies and W. L. Worrell, "Electrochemical Characterization of Mixed Conducting $\mathrm{Ba}\left(\mathrm{Ce}_{0,8-8 \mathrm{y}} \mathrm{Pr}_{\mathrm{y}} \mathrm{Gd}_{0,2}\right) \mathrm{O}_{2,9} \quad$ Cathodes" $J$. Electrochem. Soc. 148 [1] A82-A86 (2001)

54. A. Magrasó, R. Haugsrud, M. Segarra and T. Norby, "Defects and transport in $\mathrm{Gd}$-doped $\mathrm{BaPrO}_{3}$ " J. Electroceramics 23 [1] 80-88 (2009)

55. M. Shang, J. Tong and R. O'Hayre, "A promising cathode for intermediate temperature protonic ceramic fuel cells: $\mathrm{BaCO}_{0.4} \mathrm{Fe}_{0.4} \mathrm{Zr}_{0.2} \mathrm{O}_{3-\delta}$ RSC Adv. 3 15769-15775 (2013)

56. C. Duan, J. Tong, M. Shang, S. Nikodemski, M. Sanders, S. Ricote, A. Almansoori and R. O'Hayre, "Readily processed protonic ceramic fuel cells with high performance at low temperatures" Science. 349 [6254] 1321-1326 (2015)

57. H. An, H.-W. Lee, B.-K. Kim, J.-W. Son, K. J. Yoon, H. Kim, D. Shin, H.-I. Ji and J. - H. Lee "A $5 \times 5 \mathrm{~cm}^{2}$ protonic ceramic fuel cell with a power density of $1.3 \mathrm{Wcm}^{-2}$ at $600^{\circ} \mathrm{C}$ " Nature Energy 3, $870-875$ (2018)

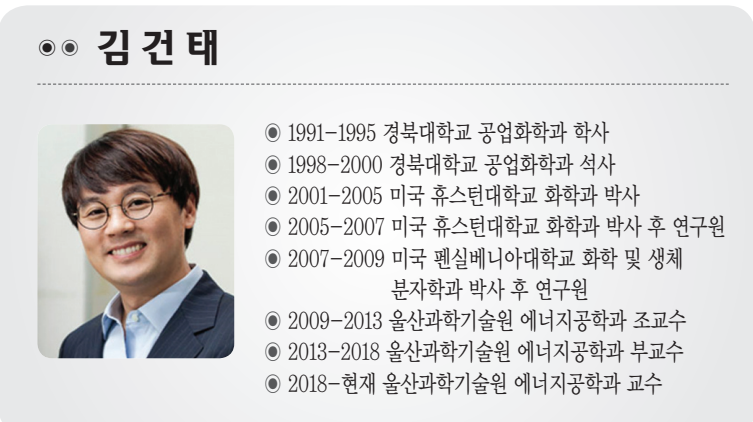

